\title{
Teaching Computational Thinking: are we considering students' socio-cultural context?
}

Original Title: Aspectos do Contexto Sociocultural dos Alunos estão Presentes nas Pesquisas para Ensinar Pensamento Computacional?

\section{Júlia S. B. Ortiz, Carolina Moreira Oliveira, Roberto Pereira}

Programa de Pós-Graduação em Informática, Universidade Federal do Paraná (UFPR) - Curitiba, PR - Brasil

\begin{tabular}{|c|c|}
\hline ARTICLE INFO & ABSTRACT \\
\hline $\begin{array}{l}\text { Article history: } \\
\text { Received } 27 \text { February } 2019 \\
\text { Accepted } 07 \text { April } 2020 \\
\text { Available online } 05 \text { May } 2020\end{array}$ & $\begin{array}{l}\text { INTRODUCTION: Research to promote Computational Thinking (CT) has become } \\
\text { frequent and carried out with the most different characteristics. Educational } \\
\text { researchers argue that learning research needs to consider aspects of students' socio- } \\
\text { cultural context, regardless of what tools are being used and the contents involved. } \\
\text { However, it is not known if, and to what extent, these aspects are being considered in } \\
\text { research to promote CT. OBJECTIVE: This research investigates whether the }\end{array}$ \\
\hline $\begin{array}{l}\text { Keywords: } \\
\text { Computational thinking } \\
\text { Informatics in Education } \\
\text { Human-Computer Interaction }\end{array}$ & $\begin{array}{l}\text { context and, mainly, how this is occurring. METHOD: A systematic mapping of the } \\
\text { literature covering a decade (2007-2017) of papers published in the main vehicles of } \\
\text { Computer Science in Education and Computer Science, considering the Brazilian and } \\
\text { international scenarios. RESULTS: Data indicates that students' socio-cultural } \\
\text { context is not being considered in the reported activities, although there is evidence } \\
\text { the scenario may be starting to change. CONCLUSION: Results show there are a } \\
\text { growing concern and an evident effort by research to bring relevant elements of }\end{array}$ \\
\hline ISSN: $2595-9077$ & $\begin{array}{l}\text { terms of rigor for the characterization of these aspects and in a theoretical basis for } \\
\text { informing research. }\end{array}$ \\
\hline DOI: JCThink.2019.v3.n1.p3 & \\
\hline
\end{tabular}

\section{Introduction}

The term Computational Thinking (CT) is relatively new in Computer Science, having appeared around 2006 with Wing's viewpoint, but this ability has been studied since Papert (1980). Currently, different definitions are accepted for the term, which converges to the potential that this skill can offer. CT is about knowing how to use the computer as an instrument to increase human cognitive and operational power and to use these resources to increase productivity, inventiveness, and creativity (Blikstein, 2008). CT involves solving problems, designing systems and understanding human behavior based on the fundamental concepts of Computer Science (Wing, 2006).

In a workshop on the scope and nature of CT (NRC, 2010), promoted by the National Research Council, one of the ideas defended by several researchers is that a person who thinks computationally realizes that computational modeling can help to approach and understand complex problems from diverse contexts, such as climate change and economic policy.

As a skill that uses fundamental Computer Science's techniques to solve problems, CT promotes the understanding of the world and the technologies that permeate it, reflecting not only on human productivity and creativity but mainly on personal autonomy, in the exercise of citizenship and equal rights and opportunities. Hence, several initiatives are being carried out to teach CT to different audiences, in the most varied configurations regarding the duration of each initiative, the way the contents are involved, and the tools used (Ortiz and Pereira, 2018).

Despite the differences in each research, Baranauskas and Carbajal (2017) argue that a project to include computational technologies in formal learning environments should be built considering everyone involved in this space, highlighting that, the more the educator dive in students' cultural and social waters, the more the knowledge will 
become accessible for the students (Freire apud Pelandré, 2002). However, although considering aspects from students' socio-cultural context is important to promote learning, whether and how these aspects have been considered by the initiatives to develop CT is an open question.

Considering the popularization of CT after Wing's (2006) viewpoint, the purpose of this paper is to analyze whether the initiatives to teach CT, published after the popularization of the term, are recognizing and exploring aspects of the students' sociocultural context, as their interests, needs, what they want to learn or what are the problems in their neighborhood they would like to solve, and, especially, how this is happening. For this purpose, a Systematic Mapping Study investigated the research published between 2007 and 2017 in the main publication vehicles of Computer Science and Computer Science in Education, considering papers written in English or Portuguese ${ }^{1}$, covering the Brazilian and international scenarios.

A total of 468 papers were found, from which 46 were selected to compose the final sample. From the extracted data, it was found that the students' socio-cultural context is not being considered in the published initiatives, although there are indications the scenario may be starting to change, as $11 \%$ of studies mention attempts to consider them. Results also revealed several issues that can be improved in future research, such as: knowing the target audience of the initiatives previously, exploring the potential of participatory practices, and promoting moments to socialize about the learning experience. Additionally, suggestions on how to address each one of the issues are presented. For the next sections, the method applied for the systematic mapping of literature, the results and the discussions resulting from this process are presented.

\section{Systematic Literature Mapping}

A Systematic Mapping of Literature was carried out to analyze whether and how the initiatives to promote CT published between 2007 and 2017 have considered aspects of the students' socio-cultural context. This study was conducted following the guidelines of Petersen et al. (2015) and included the stages of searching for papers and three stages of paper filtering. The following research questions have been defined:

- RQ1 - What are the initiatives' target audience?

- RQ2 - Are the students' context being considered by the initiatives?

- RQ3 - Are participatory practices being mentioned? What are the goals?

- RQ4 - Where are the activities taking place?

- RQ5 - Is there a moment dedicated to socializing the results of the initiatives taking place?

- RQ6 - Are students' opinions about the initiatives being investigated through the evaluation methods?

- $\quad$ RQ7 - What were the difficulties encountered during the initiatives?

In the search phase, all papers having the term "Computational Thinking" or "Pensamento Computacional" in their titles, and abstracts, published between 2007 and 2017, written in Portuguese or English, were considered. Four digital libraries were

1 Portuguese is the authors' first language and the official language in Brazil. The authors wanted to have a panorama of the Brazilian research published in Portuguese as well as in English. 
used: $\mathrm{ACM}^{2}$, IEEE Explore ${ }^{3}$, Springer ${ }^{4}$ and the library of the Brazilian Special Committee of Informatics in Education ${ }^{5}$ (CEIE). These digital libraries were chosen for their relevance in the research community, for bringing together a large number of publications in Computer Science and for addressing both the Brazilian and international scenarios.

The search returned a total of 468 papers. After the search, the inclusion criteria were applied. In the first filter, papers were selected based on their titles and abstracts. The inclusion criteria used was: IC1. Research that reports initiatives (e.g. workshops, courses, activities) to teach CT to students at any educational level. All 468 selected papers were submitted to the first filter, remaining 222 papers. The complete reading of the papers was performed in the second filter, in which the following exclusion criteria were applied:

- EC1 - Papers not written in English or Portuguese.

- EC2 - Papers not available for full access.

- EC3 - Duplicate papers (when there were two or more papers on the same initiative, the most recent or complete was kept).

- EC4 - Papers that report instructing teachers to apply activities related to CT.

- EC5 - Papers of any nature that do not characterize practical interventions with students.

After the second stage, the 62 remaining papers were submitted to a quality criterion. For this mapping, the papers which did not characterize the practices or made it impossible to understand and replicate them were excluded. This criterion was applied because this mapping aimed to select research that actually presents and discusses practices to promote the development of Computational Thinking. After this stage, the sample included 46 papers. The filtering process performed in the systematic mapping with the respective quantities of papers per digital library is presented in Figure 1.

To support the data extraction process, a template was developed including, for each extraction question, a predetermined answers. In order to characterize the sample found, besides the data to answer the research questions, basic information of papers such as publication year and researcher institutions were collected. A dataset with information from the 46 papers is available online 6 . A table, with ID, year of publication, paper title and authors' names are available in Appendix A.

\footnotetext{
2 Available on: https://dl.acm.org/dl.cfm

3 Available on: https://ieeexplore.ieee.org

4 Available on: https://www.springer.com/

5 Available on: http://www.br-ie.org/pub/index.php

6 Available on: https://bit.ly/2K46ew9
} 


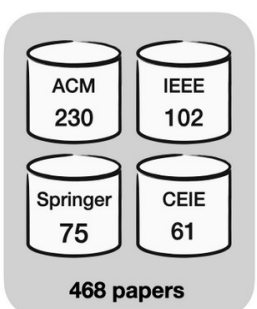

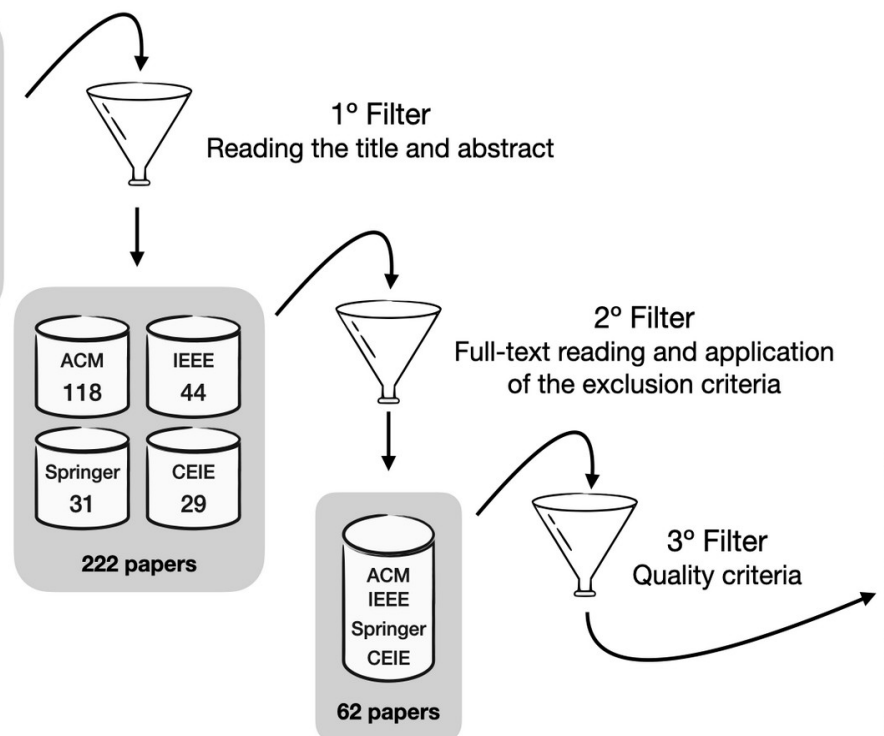

Figure 1. The papers selection process.

\section{Results}

For a better understanding of the scenario covered by this mapping, before answering the research questions we present some characteristics of the selected papers.

\subsection{General characteristics about the selected papers}

Papers from 12 countries were selected for this mapping. In some cases, papers were coauthored by researchers from universities in different countries, so the same paper was counted for all countries involved. Among the 46 papers, the number of papers published per country was: United States (21); Brazil (15); Italy (4); Spain (3); Germany (2); and Canada, India, Taiwan, Israel, Chile, Scotland and Argentina with 1 paper each. Figure 2 shows the research distribution around the world.

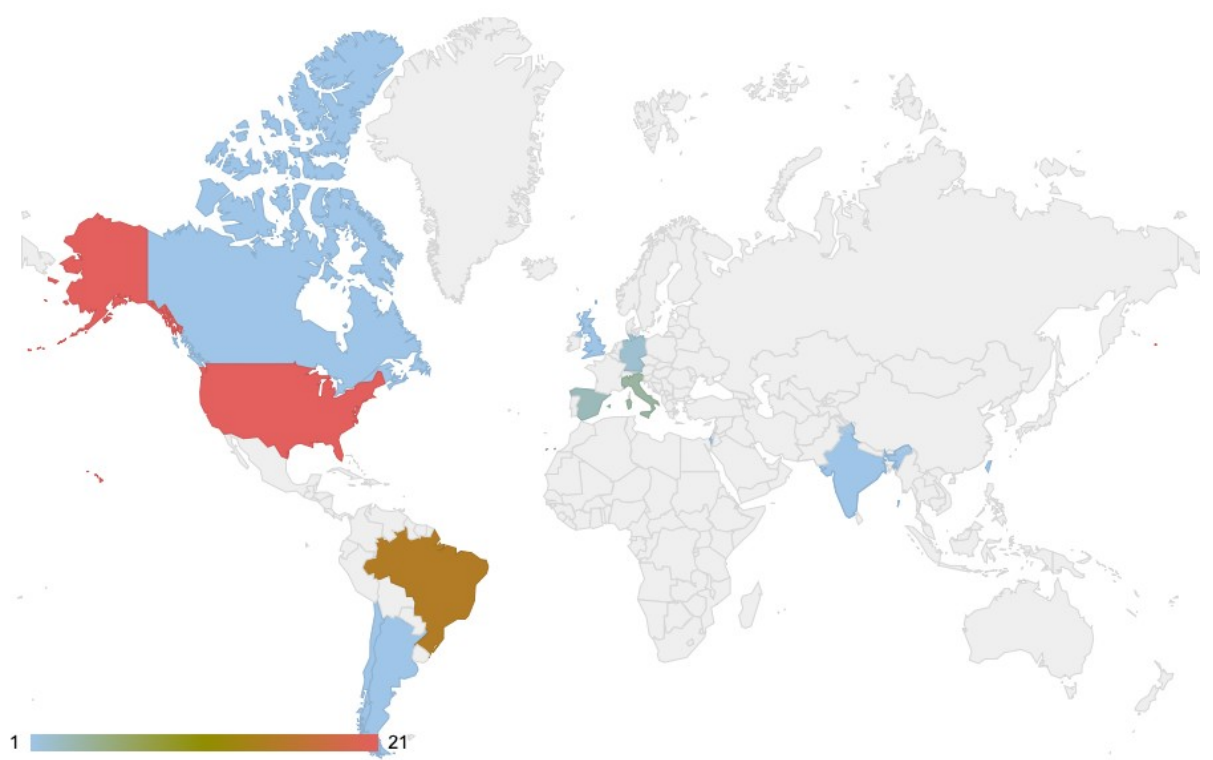

Figure 2. Research distribution around the world

One possible reason for Brazil's expressive number of selected papers is because we considered a Brazilian digital library and papers published in Portuguese, as from the 15 papers published by Brazil, only 2 papers are international, originated from 
partnerships with institutions in Chile, Argentina, and Spain. The remaining works were published in Portuguese in Brazilian events. Other countries, such as Spain, Italy, and Germany could have presented significant quantities if the mapping had included national bases from these countries or their native languages.

About papers' distribution over time, although the review covered papers published between 2007 and 2017, the oldest research found was published in 2009 by researchers from the United States. This first research aimed to teach physics and chemistry content with CT for undergraduate students. In Brazil, the oldest publication on the theme appeared only in 2015, reporting activities in high school. The number of Brazilian published research per year was: 2015: 4, 2016: 6, and 2017: 5, demonstrating how CT has become focus of Brazilian researchers. However, we infer that initiatives to develop CT in Brazil are recent, still in its first decade.

\section{RQ1 - What is the target audience of the initiatives?}

To answer this question, extracted data were normalized and categorized according to age and school level, since each paper specified them in different forms. Table 1 presents the categories found and the distribution of research among them, in quantity and percentage. According to the presented data, it is possible to observe that much focus is being given to Elementary and High School Education (70\%) and that other audiences remain as opportunities for further research.

\begin{tabular}{lcc}
\hline Target audience & Amount. & $\%$ \\
\hline Elementary School & 20 & $44 \%$ \\
High School & 8 & $17 \%$ \\
Elementary and high school & 4 & $9 \%$ \\
\hline General undergraduate and graduate & 9 & $19 \%$ \\
Undergrad in Computer Science & 4 & $9 \%$ \\
\hline Youth and Adults Education & 1 & $2 \%$ \\
\hline
\end{tabular}

Table 1. Number of initiatives found by school level.

Analyzing the predominant target audience of the Brazilian initiatives, we have that 93\% (14) occurred in Elementary and High School. Therefore, as the general scenario found, Brazil has concentrated its research almost entirely on basic education, having only one research in a different audience, the Youth and Adults Education (Ortiz and Raabe, 2016). There were no studies with undergrad or graduate students in Brazil.

\section{RQ2 - Are the students' context being considered by the initiatives?}

The data obtained indicate that students' socio-cultural context is not being considered in the activities. Among the selected papers, 89\% (41) do not mention having considered the students' context. Two possible explanations: a) this characteristic is not being reported in the papers, indicating both a lack of prioritization and a lack of rigor in initiative documentation and description, or b) indeed the students' context has not been considered in the selected research.

Regarding the five papers that mention this characteristic, Hinterholz et al. (2015) mention that the places where students go were used as an example of concept application. To find out what those places were, it was necessary to carry out an investigation. Later, in the same research, students were able to choose the themes of the activity they would work on, such as: soccer, fashion, and commerce. 
Rodrigues et al. (2015) and Santana et al. (2017) describe that students could choose the theme of the digital game that was being developed. In the paper of Munoz et al. (2016), the students were able to select real-world situations and mechanics to implement in a game. Finally, Leonard et al. (2016) mentioned that students were able to bring elements of culture to be represented in the final projects.

We observed that the initiatives focused on actions to get to know a little more about the participating students and identify their preferences to motivate them to carry out the proposed activities. That is, to make them practice the knowledge taught with activities that involve subjects of their interest. However, there was no evidence of a broader understanding of the context, which includes elements of the students' lives, their relationships, difficulties, social and economic conditions, etc. Thus, no study was identified carrying out activities situated in the students' context to engage in learning, such as selecting situations or problems in students' daily lives to propose solutions using the knowledge they want to practice.

Of these five papers, four were published by Brazilian institutions (one in partnership with Chile) and 1 published by the United States. Thus, it is concluded that few initiatives explicitly bring the students' socio-cultural context into the classroom, with $11 \%$ of the general amount of research (5) and $27 \%$ of Brazilian research (4).

The socio-cultural context is important and beneficial in any situation where the objective is learning. However, if in more homogeneous societies it is already important to consider the students' socio-cultural context to bring significant elements to the learning experience, in more diverse societies, such as the Brazilian one, marked by cultural diversity and deep inequality, it is even more. Therefore, especially for challenging conditions, it is extremely important to understand the context and bring elements as a way to enhance inclusion and respect for diversity, in addition to enhancing learning.

\section{RQ3 - Are participatory practices being mentioned? What are the goals?}

Originating in the 1970 s in Norway, Participatory Design is characterized by its political, democratic dimension, related to the strengthening of the users' role in decisions about design products that affect them in their work context. These "design products" can be processes, software systems, physical objects, teaching activities or curriculum structures, for example. Participatory practices are tools that allow all participants to have space to express their ideas about the design product being discussed.

In this sense, participatory practices are viable options for the education scenario, as they have the potential to promote a democratic space to express opinions and ideas. The resulting product may have a design that, created in a participatory way, communicates an understanding of the needs and the socio-cultural context of everyone involved, students, teachers, family members, and other relevant stakeholders.

Among the selected papers, only four mention having used participatory practices in the execution of activities, and used: storytelling (Qin, 2009), (Miller et al., 2013) and (Reis et al., 2017) and storyboard (Fronza et al., 2017). Of these 4 papers, 2 were published by authors from institutions in the USA, 1 from Brazil, and 1 from Italy. Although the research by Hinterholz et al. (2015), Rode et al. (2015) and Fronza et al. (2015) do not directly report participatory practices, they present activities in which students had the liberty to decide what they would like to work on, being 1 published by a Brazilian institution, 1 by U.S. institutions with Germany, and 1 by Italy.

In analyzing the purpose of using participatory practices in each research, we observed their use was primarily intended to engage students and did not mean that 
learners had a chance to decide/influence on any topic or activity of the initiative conducted. Participatory practices were not used to get to know aspects of the students' context, but rather to thematize activities or to make them fun, such as storytelling to tell a book activity and then working on the proposal already presented.

Participatory practices could be explored to investigate common situations among the participants, aligned with the content to be worked on. Also, it is possible to use participatory practices in student teams, making them decide together how they will solve a proposed problem.

\section{RQ4 - Where are the activities taking place?}

The place where activities are conducted can influence students' behavior, their expectations and even shape the attitude of teachers/researchers who are conducting the research. Although it is relevant to characterize and report where the research took place (settings), 11 (24\%) papers do not mention such information.

For the papers that inform the research place, formal learning spaces such as schools and universities were the most used, appearing in $94 \%$ of the initiatives that present such information ( $70 \%$ of the total). Possibly, this is due to the easiness of involving the public in these spaces, and the educational infrastructure present. Of the works, 44\% (20) were conducted in schools, 28\% (13) in Universities, $2 \%$ (1) in a computer club, $2 \%$ (1) occurred online, and 24\% (11) did not present information about the place where the research took place.

\section{RQ5 - Is there a moment dedicated to socializing the results of the initiatives taking place?}

We consider socialization as a stage that aims to present the activities developed and their results, which can occur both among classmates, in groups, and for people outside the initiative, such as other teachers, family members, friends, among others.

Of the 46 selected papers, only 2 mention a socialization stage. The paper by Santana et al. (2017) mentions a presentation of the final works to a team of evaluators, teachers, parents, and guests. In the research by Webb et al. (2013), parents and family members were invited to an exhibition event of the projects developed by the students. The low number of research that reports socialization may indicate two situations: a) the socialization stage is happening, but it is not being documented and reported; or b) moments of socialization of the results produced by the participants are not being carried out.

Moments of socialization can bring several benefits to those involved. For students, in addition to exercising the ability to synthesize and expose ideas, it allows them to visualize different ways to solve problems, enriching the learning experience and exercising critical and creative ability when analyzing other possibilities and points of view. Socializing with the community provides society a return of the knowledge generated, broadening the scope of the initiative and possibly receiving inputs for new activities. For researchers, socialization provides a moment of reflection, identification of lessons learned, new ideas and results, exposing the results of research, and may eventually attract support for future initiatives.

\section{RQ6 - Are students' opinions about the initiatives being investigated through the evaluation methods?}

Obtained data allow us to observe the diversity of aspects evaluated by the selected initiatives, with different methods of evaluation. All the evaluation methods with their respective quantities are presented in Table 2. As several papers used more than one 
type of evaluation, the sum of the quantities in each method used exceeds the total number of research. Of the selected paper, only two papers do not mention the evaluation method used.

\begin{tabular}{lc}
\hline Evaluation Method & Amount \\
\hline Survey & 17 \\
Comparison between Pre and Post Test & 9 \\
Researchers observation & 9 \\
Analysis of the developed project & 6 \\
Students interview & 5 \\
Students feedback & 3 \\
Course grades & 3 \\
Control group vs. experimental & 2 \\
\hline
\end{tabular}

Table 2. Evaluation methods cited in the selected papers.

The different methods of evaluation are related to the objective and context of each research. For example: the initiatives that chose for the comparison between the control group and the experimental group aimed to compare teaching methods, while the initiatives that opted for the comparison between pre and post-test may have aimed to quantify the students' learning about new content as a result of a specific intervention.

All the initiatives involve students, however, only 44\% (20) of the research involved evaluations that explicitly allow free expression of the student about the initiative conducted. Besides, although some of the evaluation methods used allow the student to respond freely, as may be the case with questionnaires, feedback, and interviews, it is not always ensured that students' opinions and perceptions about the initiative are being investigated.

\section{RQ7 - What were the difficulties encountered during the initiatives?}

Of the 46 selected papers, 34 do not mention any difficulties, which may indicate: a) that they did not actually face significant difficulties to the point of being reported, or b) that they were not documented, which may also indicate a lack of rigor in the description of research. The other 12 papers mention difficulties related to several factors that were divided into 3 groups: (1) knowing the target audience; (2) curriculum of courses and ways of associating diverse disciplines with Computational Thinking; and (3) infrastructure.

The first group concerns problems related to the lack of knowledge about the target audience, which can contribute to a lack of engagement and interest of students, identified in 6 papers. The paper by HSI et al. (2012) and Ortiz and Raabe (2016) mention that the lack of knowledge about the target audience leads to difficulty in equalizing the level of knowledge of the class, making it difficult to identify which activities would be appropriate considering the subjects that were being taught to students. Qin (2009) reports having considered, when designing the activities, that students were at a more advanced level of knowledge than what was observed later in the classroom.

The authors Krugel and Hubwieser (2017) mention that if working with complex real-life problems, students would need to learn a significant amount of new concepts at once. On the other hand, Miller et al. (2013) mention that, when using CT exercises with critical thinking, which involves a certain level of abstraction, the connections 
between the exercises and the CT principles were not so evident, leading students to question the relevance and benefits of doing the exercises.

Towhidnejad et al. (2014) mention that, at the beginning of the course, they were unable to attract students' interest, so some activities needed to be reformulated in an attempt to revert this situation. In these cases, it is desirable to know more about the target audience before not only the beginning of classes but at the beginning of planning activities will be part of the initiative.

In the second group are 3 papers that report problems related to the curriculum of the courses and ways of associating different subjects with CT. Qin (2009) mentions difficulties in teaching Computer Science concepts to Science/Biology students. The author reports that even though students believe that CT can improve their skills, they generally do not choose courses related to technology because they imagine they are intended for students of Computing and Engineering only. The author also mentions difficulties in accessing online tools due to new rules for using the laboratory, either altered by the institution or by changes in the tool.

Ruthmann et al. (2010) propose a course to teach music and associated computational concepts, both for students of Music and Computing courses. The authors report that they had difficulty to convince the university that the course would take place, that the course would provide technology students with music knowledge and vice versa. In line with interdisciplinary courses, Senske (2017) mentions that at the beginning of the course, architecture students thought that CT had no relation to their education. In the aforementioned cases, exploring the transdisciplinarity of the CT can be an alternative, as long as it is equalized with the former knowledge of the students, already assessed previously, giving practical examples in everyday situations.

The last group brings together 3 papers that present infrastructure difficulties, such as lack of equipment and access to the necessary tools. The lack of resources in schools was pointed out as a difficulty by the papers such as (Silva et al., 2016) and (Gauta et al., 2017). Corradini et al., (2017) report several problems, such as lack of devices, a material made available by the tool (originally in English), platform restriction, among others. In these cases, exploring unplugged techniques is a viable alternative because they can occur in the most diverse environments, internal and external, regardless of the electrical network or internet connection, requiring only creativity and planning from researchers.

\section{Discussion}

The data obtained and the research questions answered to characterize the scenario reflect the digital libraries where the papers were found and need to be understood within the defined scope for this study. A table containing the extracted data is available to be audited and verified by the reader, allowing an extension of this study to other digital libraries or longer periods of search.

Research in education has shown how important it is to involve students' sociocultural context in all initiatives aimed at promoting learning, so the content becomes more "available" to students and improves their engagement in the teaching-learning process, regardless of whether they are children or adults (Freire, 1997).

Projects that aim to work with computer technologies in formal learning spaces, such as schools and universities, must involve the contexts that surround and permeate these spaces, especially the students' ones. Through the results of a Systematic Literature Mapping, we identified 46 papers that report practical activities with students and observe that these were precisely the places where about $95 \%$ of the mapped initiatives occurred (33 of 35, as 11 papers did not specify). However, the socio-cultural 
context of students is being little explored in initiatives, being mentioned in only $11 \%$ of the cases ( 5 of the 46 papers).

Analyzing the data, we observed that participatory practices already appear as an instrument of research (4 out of 46), but they can still be further explored in their diversity. Participatory practices have great potential for engagement and are capable of giving space for all students to manifest themselves dynamically and democratically, being able to bring up issues of their contexts, their preferences, wills, expectations among others, as long as they are correctly directed. Muller et al. (1997) present more than 60 participatory practices to be used in the software development process and which have been explored in other contexts, such as the teaching of Computational Thinking (Schultz et al., 2018). However, we highlight that only asking students about their preferences is not enough. The notion of participation must be as wide as possible.

If, on the one hand, bringing students' context into the classroom is important, on the other hand, it is necessary to socialize the knowledge produced to reinforce the learning process. This reinforcement would provide the exercise of synthesis and communication capacities, showing colleagues different ways of solving the same problem, involving different approaches, different methods and tools, and also providing contact with other people, the knowledge generated and the lived experience. This socialization moment was observed in only 2 of the 46 papers.

Regarding the evaluation methods, we observed that several of them were used for different purposes. It is expected that initiatives aimed at teaching some content would use quantitative methods to measure students' progress. However, when it comes to experimental initiatives, that involve different tools and techniques, obtaining the opinion about the initiatives from students and other stakeholders involved is important, and this situation was observed in $44 \%$ of the mapped research, less than a half. This suggests that, even when there is research with participants, it is still common to have a posture focused on observation and data, often missing the opportunity to obtain complimentary or qualitative information from participants that could reinforce or explain the results obtained and the observations made. This allows us to state that, although we are claiming more participatory strategies and didactic methods in the classroom, in our research students still tend to be considered as subjects being observed instead of effective and active participants in the actions carried out.

As a result of the answers to the research questions in this Systematic Literature Mapping, we identified as points to be explored by future research:

1. Rigor: pay attention to the accuracy of information description and characterization of actions so that the level of the specification allows, for example, replicating the study, reconstitute researcher's steps, and understanding research rationale.

2. Approximation: plan and carry out activities in which the content learned is related to the students' socio-cultural context and as close as possible to that context.

3. Immersion: previously know the target audience of the initiatives, before developing the activities, in order to be aware of the needs and expectations of the participants, eliminate knowledge incompatibilities and facilitate the proposal of ideas to conduct the activities.

4. Socialization: promote moments of socialization about the learning experience, at least among the students themselves, but not restricted to them. 
5. Responsibility: to investigate students' opinions about the initiatives, not only about what was learned but also about how the learning moments were conducted, if they used the knowledge acquired in other contexts, etc.

\section{Conclusion}

Computational Thinking is a skill that has been gaining space in the scientific community and each year new papers report initiatives aimed at teaching this skill for different audiences. This paper analyzed whether and how the socio-cultural context of students is being considered in CT initiatives, also investigating the participatory practices being reported, what are the difficulties encountered, among others. To this end, a Systematic Mapping of Literature was carried out, covering the research published between 2007 and 2017, written in English or Portuguese, in 4 digital libraries. From a total of 468 papers found, 46 papers were selected after applying inclusion, exclusion, and quality criterion.

The extracted data were analyzed, and we found that the students' socio-cultural context is not being considered in the activities, although there are indications that the scenario may be starting to change. We observed that some aspects of socialization, values, and society are present in the mapped initiatives (5 of 46), however, only to serve as themes for the activities. Some papers used participatory practices, but without exploring all the potential they can offer. We also found that difficulties mentioned in the papers are related to several factors, indicating that, in this type of research, obstacles of different natures may arise.

Results reveal research in CT is recent and growing, with opportunities for reaching more diverse audiences, exploring different contents and contexts. Research rigor and reproducibility can be improved as research in the field advances with results from empirical studies as well with progress in theories and methods. This paper offers a panorama of literature in CT reporting results of practical initiatives to promote its development, having the potential to inform and situate researchers and practitioners working in the field.

\section{Acknowledgment}

This paper is a translated, extended and revised version of a paper entitled (in Portuguese) "Aspectos do Contexto Sociocultural dos Alunos estão Presentes nas Pesquisas para Ensinar Pensamento Computacional?" published at the IV Workshop on Teaching of Computational Thinking, Algorithms and Programming (WAlgProg). The authors thank the Editors for the invitation. This paper is partially supported by the Coordination for the Improvement of Higher Education Personnel - Brazil (CAPES) Financing Code 001.

\section{References}

BARANAUSKAS, M.C.C. Social Awareness in HCI. Interactions, vol. 21, no. 4, pp 66-69, 2014.

BARANAUSKAS, M.C.C.; CARBAJAL, M.L. The Social Nature of Programming: Children and Fluency, vol. 10272, 2017.

BARR, V.; STEPHENSON, C. Computational Thinking to k-12: What is Involved and What is the Role of the Computer Science Education Community? ACM Inroads, vol. 2, no. 1, pp 48-54, 2011. 
BLIKSTEIN, P. O Pensamento Computacional e a Reinvenção do Computador na Educação. 2008.

CORRADINI, I.; LODI, M.; NARDELLI, E. Computational Thinking in Italian Schools: Quantitative Data and Teachers' Sentiment Analysis after Two Years of "Programma il Futuro". In Proceedings of the 2017 ACM Conference on Innovation and Technology in Computer Science Education (ITiCSE '17). New York, NY, USA, pp 224-229.

COUNCIL, N.R. Report of a Workshop on the Scope and Nature of Computational Thinking. The National Academies Press, Washington, DC, 2010.

FREIRE, P. (1997). Pedagogia da autonomia: Saberes necessários à prática educativa. Paz e Terra.

FRONZA, I.; El IOINI, N.; CORRAL, L. Students Want to Create Apps: Leveraging Computational Thinking to Teach Mobile Software Development. In Proceedings of the 16th Annual Conference on Information Technology Education (SIGITE '15). New York, NY, USA, 2015, pp 21-26.

FRONZA, I.; IOINI, N. E.; CORRAL, L. Teaching Computational Thinking Using Agile Software Engineering Methods: A Framework for Middle Schools. ACM Transactions on Computing Education (TOCE), vol. 17, no. 4, 2017.

GAUTAM, A.; BORTZ, W. E. W.; TATAR, D. Case for Integrating Computational Thinking and Science in a Low-Resource Setting. In Proceedings of the Ninth International Conference on Information and Communication Technologies and Development (ICTD '17). New York, NY, USA, 2017.

HINTERHOLZ, L.; CRUZ, M. K. Desenvolvimento do Pensamento Computacional: um relato de atividade junto ao Ensino Médio, através do Estágio Supervisionado em Computação III. In Anais do Workshop de Informática Na Escola, 2015.

HSI, S.; EISENBERG, M. Math on A Sphere: Using Public Displays to Support Children's Creativity and Computational Thinking On 3D Surfaces. In Proceedings of The 11th International Conference On Interaction Design And Children (IDC '12). New York, NY, USA, 2012, pp 248-251.

KRUGEL, J.; HUBWIESER, P. Computational Thinking as Springboard for Learning Object-Oriented Programming in an Interactive MOOC. IEEE Global Engineering Education Conference (EDUCON), Athens, 2017, pp. 1709-1712.

LEONARD, J.; BUSS, A.; GAMBOA, R.; MITCHELL, M.; FASHOLA, O. S.; HUBERT, T.; AL-MUGHYIRAH, S. Using Robotics and Game Design to Enhance Children's Self-Efficacy, STEM Attitudes, and Computational Thinking Skills. In Journal of Science Education and Technology, 2016, vol. 25, no. 6, p p 860-876.

LIU, K. Semiotics in Information Systems Engineering. Cambridge University Press, 2000 .

MILLER, L. D.; SOH, L. K.; CHIRIACESCU, V.; INGRAHAM, E.; SHELL, D. F.; RAMSAY, S.; HAZLEY, M. P. Improving Learning of Computational Thinking Using Creative Thinking Exercises in Cs-1 Computer Science Courses. In IEEE Frontiers in Education Conference (FIE), Oklahoma City, OK, 2013, pp. 1426-1432. 
Muller MJ, Haslwanter JH, Dayton T. Participatory practices in the software lifecycle. In Handbook of human-computer interaction 1997 Jan 1 (pp. 255-297). North-Holland.

NCSU; CENTER FOR UNIVERSAL DESIGN. Principles of Universal Design. 1997.

ORTIZ, J. S. B.; PEREIRA, R. (2018). Um Mapeamento Sistemático Sobre as Iniciativas para Promover o Pensamento Computacional. In Anais do XXIX Simpósio Brasileiro de Informática na Educação (SBIE 2018). Vol. 29. No. 1. 2018.

ORTIZ, J. B.; RAABE, A., (2016) Pensamento Computacional na Educação de Jovens e Adultos: Lições Aprendidas. In Anais dos Workshops do Congresso Brasileiro de Informática na Educação (WCBIE 2016). Vol. 5. No. 1. 2016.

PELANDRÉ, N.L. Ensinar e Aprender com Paulo Freire: 40 horas 40 anos depois. Cortez Editora e Editora da UFSC. 2002.

PEREIRA, R.; BARANAUSKAS, M.C.C. A Value-Oriented and Culturally Informed Approach to the Design of Interactive Systems. International Journal of HumanComputer Studies, vol. 80, pp 66-82, 2015.

PETERSEN, K.; VAKKALANKA, S.; KUZNIARZ, L. Guidelines for Conducting Systematic Mapping Studies in Software Engineering: An update. Information and Software Technology, vol. 64, pp 1-18, 2015.

QIN, H. Teaching Computational Thinking Through Bioinformatics to Biology Students. In Proceedings of the 40th ACM Technical Symposium on Computer science Education (SIGCSE '09). New York, NY, USA, 2009, pp 188-191.

REIS, F. D. M.; CRISTIANO, F.; MARTINS, D.; ROCHA, P. D. Pensamento Computacional: Uma Proposta de Ensino com Estratégias Diversificadas para Crianças do Ensino Fundamental. In Anais do Workshop de Informática na Escola, 2017.

RODE, J. A.; WEIBERT, A.; MARSHALL, A.; AAL, K.; VON REKOWSKI, T.; EL MIMOUNI, H.; BOOKER, J. From Computational Thinking to Computational Making. In Proceedings of the 2015 ACM International Joint Conference on Pervasive and Ubiquitous Computing (UbiComp '15). New York, NY, USA, 2015, pp 239-250.

RODRIGUEZ, C.; ZEM-LOPES, A. M.; MARQUES, L.; ISOTANI, S. Pensamento Computacional: Transformando Ideias em Jogos Digitais Usando o Scratch. In Anais do Workshop de Informática na Escola, 2015.

RUTHMANN, A.; HEINES, J. M.; GREHER, G. R.; LAIDLER, P.; SAULTERS, II, C. Teaching Computational Thinking Through Musical Live Coding in Scratch. In Proceedings of the 41st ACM Technical Symposium on Computer Science Education (SIGCSE '10). New York, NY, USA, 2010, pp 351-355.

SANTANA, A. L. M.; DE JESUS, E. A.; RAABE, A.; SANTANA, L.; CUCCO, L.; RAMOS, G. Tem Ideia na Rede: Inserindo o Pensamento Computacional na Rede Municipal de Ensino. In Anais do Workshop de Informática na Escola (WEI), 2017.

SCHUlTZ, E. P. B; ORTIZ, S. B.; GARCÍA, L. S; PEREIRA, P. Teaching Game Design and Basic Computing Concepts: a Democratic Experiment in a Socioeconomically Vulnerable Community. In XXIX Simpósio Brasileiro de Informática na Educação, 2018. 
SBC. Referenciais de Formação em Computação: Educação Básica. pp 1-9, 2017.

SCHULER, D.; NAMIOKA, A. Participatory Design: Principles and Practices. L. Erlbaum Associates Inc., Hillsdale, NJ, USA, 1993.

SENSKE, N. Evaluation and Impact of a Required Computational Thinking Course for Architecture Students. In Proceedings of the 2017 ACM SIGCSE Technical Symposium on Computer Science Education (SIGCSE '17). New York, NY, USA, 2017, pp 525530.

SILVA, D. P.; SIDNEI, S.; JESUS, A.; SILVA, C. E. P. Aplicação de Robótica na Educação de Forma Gradual para o Estímulo do Pensamento Computacional. In Anais dos Workshops do Congresso Brasileiro de Informática na Educação (CBIE), 2016.

STAMPER, R.; LIU, K.; HAFKAMP, M.; ADES, Y. Understanding the Roles of Signs and Norms in Organisations. Behaviour \& Information Technology, vol. 19, pp 15-27, 2000 .

TOWHIDNEJAD, M.; KESTLER, C.; Jafer, S.; NICHOLAS, V. Introducing Computational Thinking Through Stealth Teaching. IEEE Frontiers in Education Conference (FIE) Proceedings, Madrid, 2014, pp. 1-7.

WEBB, H; ROSSON, M. B. Using Scaffolded Examples to Teach Computational Thinking Concepts. In Proceeding of The 44th ACM Technical Symposium On Computer Science Education (SIGCSE '13). New York, NY, USA, 2013, pp. 95-100.

WING, J.M. Computational Thinking. Communications of the ACM, vol. 49, no. 3, pp 33-35, 2006.

YADAV, A.; STEPHENSON, C.; HONG, H. Computational Thinking for Teacher Education. Communications of the ACM, vol. 60, no. 4, pp 55-62, 2017.

\section{Appendix A - Selected Papers}

\begin{tabular}{lllll}
\hline ID & Year & $\begin{array}{l}\text { Digital } \\
\text { Library }\end{array}$ & \multicolumn{1}{c}{ Paper Title } & \multicolumn{1}{c}{ Authors } \\
\hline 1 & 2009 & ACM & $\begin{array}{l}\text { A Multidisciplinary Approach Towards } \\
\text { Computational Thinking for Science Majors }\end{array}$ & $\begin{array}{l}\text { Hambrusch, S., Hoffmann, C., Korb, } \\
\text { J. T., Haugan, M., and Hosking, A. } \\
\text { L. }\end{array}$ \\
\hline 2 & 2009 & ACM & $\begin{array}{l}\text { Teaching Computational Thinking Through } \\
\text { Bioinformatics to Biology Students }\end{array}$ & Qin, H. \\
\hline 3 & 2010 & ACM & $\begin{array}{l}\text { Teaching Computational Thinking Through } \\
\text { Musical Live Coding in Scratch }\end{array}$ & $\begin{array}{l}\text { Ruthmann, A., Heines, J. M., } \\
\text { Greher, G. R., Laidler, P., and } \\
\text { Saulters, II, C. }\end{array}$ \\
\hline 4 & 2011 & IEEE & $\begin{array}{l}\text { A novel interdisciplinary course in } \\
\text { gerontechnology for disseminating computational } \\
\text { thinking }\end{array}$ & $\begin{array}{l}\text { Yang, H. I., Martin, P., Satterfield, } \\
\text { D., Babbitt, R., Wong, J., Shelley, } \\
\text { M., and Chang,C. K. }\end{array}$ \\
\hline 5 & 2011 & ACM & $\begin{array}{l}\text { Computational Thinking and Expository Writing } \\
\text { in the Middle School }\end{array}$ & $\begin{array}{l}\text { Wolz, U., Stone, M., Pearson, K., } \\
\text { Pulimood, S. M., and Switzer, M. }\end{array}$ \\
\hline 6 & 2011 & ACM & $\begin{array}{l}\text { CS1 Students' Understanding of Computational } \\
\text { Thinking Concepts }\end{array}$ & $\begin{array}{l}\text { A. Qualls, J., Grant, M., and } \\
\text { Sherrell, L. }\end{array}$ \\
\hline 7 & 2011 & ACM & $\begin{array}{l}\text { Initial Experience with a Computational Thinking } \\
\text { Course for Computer Science Students }\end{array}$ & \begin{tabular}{l} 
Kafura, D. and Tatar, D. \\
\hline
\end{tabular} \\
\hline
\end{tabular}




\begin{tabular}{|c|c|c|c|c|}
\hline 8 & 2012 & $\mathrm{ACM}$ & $\begin{array}{l}\text { IT Problem Solving: An Implementation of } \\
\text { Computational Thinking in Information } \\
\text { Technology }\end{array}$ & $\begin{array}{l}\text { L'Heureux, J., Boisvert, D., Cohen, } \\
\text { R., and Sanghera, K. }\end{array}$ \\
\hline 9 & 2012 & $\mathrm{ACM}$ & $\begin{array}{l}\text { Math on a Sphere: Using Public Displays to } \\
\text { Support Children's Creativity and Computational } \\
\text { Thinking on 3D Surfaces }\end{array}$ & Hsi, S. and Eisenberg, M. \\
\hline 10 & 2013 & $\mathrm{ACM}$ & $\begin{array}{l}\text { Accelerating K-12 Computational Thinking Using } \\
\text { Scaffolding, Staging, and Abstraction }\end{array}$ & $\begin{array}{l}\text { Touretzky, D. S., Marghitu, D., } \\
\text { Ludi, S., Bernstein, D., and Ni, L. }\end{array}$ \\
\hline 11 & 2013 & IEEE & $\begin{array}{l}\text { Improving learning of computational thinking } \\
\text { using creative thinking exercises in CS-1 } \\
\text { computer science courses }\end{array}$ & $\begin{array}{l}\text { Miller, L. D., Soh, L. K., } \\
\text { Chiriacescu, V., Ingraham, E., Shell, } \\
\text { D. F., Ramsay, S., and Hazley, M. P. }\end{array}$ \\
\hline 12 & 2013 & $\mathrm{ACM}$ & $\begin{array}{l}\text { Using Scaffolded Examples to Teach } \\
\text { Computational Thinking Concepts }\end{array}$ & Webb, H. and Rosson, M. B. \\
\hline 13 & 2014 & $\mathrm{ACM}$ & $\begin{array}{l}\text { Effectiveness of a Computational Thinking (CS0) } \\
\text { Course on Student Analytical Skills }\end{array}$ & Van Dyne, M. and Braun, J. \\
\hline 14 & 2014 & IEEE & $\begin{array}{l}\text { Introducing computational thinking through } \\
\text { stealth teaching }\end{array}$ & $\begin{array}{l}\text { Towhidnejad, M., Kestler, C., Jafer, } \\
\text { S., and Nicholas, V. }\end{array}$ \\
\hline 15 & 2015 & CEIE & $\begin{array}{l}\text { Desenvolvimento do Pensamento Computacional: } \\
\text { um relato de atividade junto ao Ensino Médio, } \\
\text { através do Estágio Supervisionado em } \\
\text { Computação III }\end{array}$ & Hinterholz, L. and da Cruz, M. K. \\
\hline 16 & 2015 & IEEE & $\begin{array}{l}\text { DISSECT: An experiment in infusing } \\
\text { computational thinking in a sixth grade classroom }\end{array}$ & Peel, A., Fulton, J., and Pontelli, E. \\
\hline 17 & 2015 & IEEE & $\begin{array}{l}\text { DISSECT: Exploring the relationship between } \\
\text { computational thinking and English literature in } \\
\text { K-12 curricula }\end{array}$ & $\begin{array}{l}\text { Nesiba, N., Pontelli, E., and Staley, } \\
\text { T. }\end{array}$ \\
\hline 18 & 2015 & $\mathrm{ACM}$ & $\begin{array}{l}\text { From Computational Thinking to Computational } \\
\text { Making }\end{array}$ & $\begin{array}{l}\text { Rode, J. A., Weibert, A., Marshall, } \\
\text { A., Aal, K., von Rekowski, T., El } \\
\text { Mimouni, H., and Booker, J. }\end{array}$ \\
\hline 19 & 2015 & CEIE & $\begin{array}{l}\text { Pensamento Computacional: transformando ideias } \\
\text { em jogos digitais usando o Scratch }\end{array}$ & $\begin{array}{l}\text { Rodriguez, C., Zem-Lopes, A. M., } \\
\text { Marques, L., and Isotani, S. }\end{array}$ \\
\hline 20 & 2015 & CEIE & $\begin{array}{l}\text { Significação da Aprendizagem Através do } \\
\text { Pensamento Computacional no Ensino Médio: } \\
\text { uma Experiência com Scratch }\end{array}$ & Ramos, F. and Teixeira, L. D. S. \\
\hline 21 & 2015 & $\mathrm{ACM}$ & $\begin{array}{l}\text { Students Want to Create Apps: Leveraging } \\
\text { Computational Thinking to Teach Mobile } \\
\text { Software Development }\end{array}$ & $\begin{array}{l}\text { Fronza, I., El Ioini, N., and Corral, } \\
\text { L. }\end{array}$ \\
\hline 22 & 2015 & CEIE & $\begin{array}{l}\text { Uma Experiência no Ensino de Pensamento } \\
\text { Computacional para Alunos do Ensino } \\
\text { Fundamental }\end{array}$ & $\begin{array}{l}\text { Schoeffel, P., Moser, P., Varela, G., } \\
\text { Durigon, L., de Albuquerque, G. C., } \\
\text { and Niquelatti, M. }\end{array}$ \\
\hline 23 & 2016 & IEEE & $\begin{array}{l}\text { An Experience Report on Teaching Programming } \\
\text { and Computational Thinking to Elementary Level } \\
\text { Children Using Lego Robotics Education Kit }\end{array}$ & $\begin{array}{l}\text { Chaudhary, V., Agrawal, V., Sureka, } \\
\text { P., and Sureka, A. }\end{array}$ \\
\hline 24 & 2016 & CEIE & $\begin{array}{l}\text { Aplicação de Robótica na Educação de Forma } \\
\text { Gradual para o Estímulo do Pensamento } \\
\text { Computacional }\end{array}$ & $\begin{array}{l}\text { da Silva, D. P., Sidnei, S., Jesus, A., } \\
\text { and Silva, C. E. P. }\end{array}$ \\
\hline 25 & 2016 & $\mathrm{ACM}$ & Computational Thinking As a Liberal Study & $\begin{array}{l}\text { Mason, D., Khan, I., and } \\
\text { Farafontov,V. }\end{array}$ \\
\hline 26 & 2016 & Springer & $\begin{array}{l}\text { Developing Computational Thinking Abilities } \\
\text { Instead of Digital Literacy in Primary and } \\
\text { Secondary School Students }\end{array}$ & $\begin{array}{l}\text { Segredo, E., Miranda, G., León, C., } \\
\text { and Santos, A. }\end{array}$ \\
\hline 27 & 2016 & $\mathrm{ACM}$ & $\begin{array}{l}\text { Frogs to Think with: Improving Students' } \\
\text { Computational Thinking and Understanding of } \\
\text { Evolution in A Code-First Learning Environment }\end{array}$ & $\begin{array}{l}\text { Guo, Y., Wagh, A., Brady, C., Levy, } \\
\text { S. T., Horn, M. S., and Wilensky, U. }\end{array}$ \\
\hline
\end{tabular}




\begin{tabular}{|c|c|c|c|c|}
\hline 28 & 2016 & IEEE & $\begin{array}{l}\text { Game design workshop to develop computational } \\
\text { thinking skills in teenagers with Autism Spectrum } \\
\text { Disorders }\end{array}$ & $\begin{array}{l}\text { Munoz, R., Barcelos, T. S., } \\
\text { Villarroel, R., and Silveira, I. F. }\end{array}$ \\
\hline 29 & 2016 & CEIE & $\begin{array}{l}\text { Pensamento Computacional e Robótica: Um } \\
\text { Estudo Sobre Habilidades Desenvolvidas em } \\
\text { Oficinas de Robótica Educacional }\end{array}$ & Oliveira, E. and Araujo, A. L. \\
\hline 30 & 2016 & CEIE & $\begin{array}{l}\text { Pensamento Computacional na Educação de } \\
\text { Jovens e Adultos: Lições Aprendidas }\end{array}$ & Ortiz, J. B. and Raabe, A. \\
\hline 31 & 2016 & CEIE & $\begin{array}{l}\text { Pensamento Computacional no Ensino } \\
\text { Fundamental: Relato de Atividade de Introdução a } \\
\text { Algoritmos }\end{array}$ & $\begin{array}{l}\text { Pinho, G., Weisshahn, Y., Reiser, } \\
\text { R., de Brum, C. F., Cavalheiro, S., } \\
\text { Foss, L., Aguiar, M., and Bois, A. D. }\end{array}$ \\
\hline 32 & 2016 & CEIE & $\begin{array}{l}\text { Proposta de Jogo Digital para Dispositivos } \\
\text { Móveis: Desenvolvendo Habilidades do } \\
\text { Pensamento Computacional }\end{array}$ & $\begin{array}{l}\text { Pinho, G., Weisshahn, Y., de Brum, } \\
\text { C. F., Cavalheiro, G. G. H., and } \\
\text { Cavalheiro, S. }\end{array}$ \\
\hline 33 & 2016 & $\mathrm{ACM}$ & $\begin{array}{l}\text { Teaching High School Students Computational } \\
\text { Thinking with Hands-on Activities }\end{array}$ & Li, W.-L., Hu, C.-F., and Wu, C.-C. \\
\hline 34 & 2016 & Springer & $\begin{array}{l}\text { Using Robotics and Game Design to Enhance } \\
\text { Children's Self-Efficacy, STEM Attitudes, and } \\
\text { Computational Thinking Skills }\end{array}$ & $\begin{array}{l}\text { Leonard, J., Buss, A., Gamboa, R., } \\
\text { Mitchell, M., Fashola, O. S., Hubert, } \\
\text { T., and Al-mughyirah, S. }\end{array}$ \\
\hline 35 & 2017 & $\mathrm{ACM}$ & $\begin{array}{l}\text { Case for Integrating Computational Thinking and } \\
\text { Science in a Low-Resource Setting }\end{array}$ & $\begin{array}{l}\text { Gautam, A., Bortz, W. E. W., and } \\
\text { Tatar, D. }\end{array}$ \\
\hline 36 & 2017 & IEEE & $\begin{array}{l}\text { Computational thinking as springboard for } \\
\text { learning object-oriented programming in an } \\
\text { interactive MOOC }\end{array}$ & Krugel, J. and Hubwieser, P. \\
\hline 37 & 2017 & $\mathrm{ACM}$ & $\begin{array}{l}\text { Computational Thinking in Italian Schools: } \\
\text { Quantitative Data and Teachers' Sentiment } \\
\text { Analysis After Two Years of Programma Il Futuro }\end{array}$ & $\begin{array}{l}\text { Corradini, I., Lodi, M., and Nardelli, } \\
\text { E. }\end{array}$ \\
\hline 38 & 2017 & $\mathrm{ACM}$ & $\begin{array}{l}\text { Development of Computational Thinking Skills } \\
\text { Through Unplugged Activities in Primary School }\end{array}$ & $\begin{array}{l}\text { Brackmann, C. P., Román- } \\
\text { González, M., Robles, G., Moreno- } \\
\text { León, J., Casali, A., and Barone,D. }\end{array}$ \\
\hline 39 & 2017 & CEIE & $\begin{array}{l}\text { Estudo Comparativo de Abordagens Referentes ao } \\
\text { Desenvolvimento do Pensamento Computacional }\end{array}$ & $\begin{array}{l}\text { Cândido, D., Pessoa, G., } \\
\text { Vasconcelos, B., da Silva, L. L., } \\
\text { Oliveira, R., Oliveira, M., and } \\
\text { Falcão, T. P. }\end{array}$ \\
\hline 40 & 2017 & $\mathrm{ACM}$ & $\begin{array}{l}\text { Evaluation and Impact of a Required } \\
\text { Computational Thinking Course for Architecture } \\
\text { Students }\end{array}$ & Senske, N. \\
\hline 41 & 2017 & CEIE & $\begin{array}{l}\text { O ensino do pensamento computacional como } \\
\text { forma de inclusão tecnológica e motivação de } \\
\text { crianças }\end{array}$ & Rodrigues, G. and Sousa, L. \\
\hline 42 & 2017 & CEIE & $\begin{array}{l}\text { Pensamento Computacional: Uma Proposta de } \\
\text { Ensino com Estratégias Diversificadas para } \\
\text { Crianças do Ensino Fundamental }\end{array}$ & $\begin{array}{l}\text { Reis, F. D. M., Cristiano, F., } \\
\text { Martins, D., and Rocha, P. D. }\end{array}$ \\
\hline 43 & 2017 & $\mathrm{ACM}$ & $\begin{array}{l}\text { Promoting Computational Thinking and } \\
\text { Creativeness in Primary School Children }\end{array}$ & $\begin{array}{l}\text { Chiazzese, G., Fulantelli, G., } \\
\text { Pipitone, V., and Taibi, D. }\end{array}$ \\
\hline 44 & 2017 & $\mathrm{ACM}$ & $\begin{array}{l}\text { Promoting Computational Thinking in K-12 } \\
\text { Students by Applying Unplugged Methods and } \\
\text { Robotics }\end{array}$ & $\begin{array}{l}\text { Conde, M. A., Fernández-Llamas, } \\
\text { C., Rodríguez-Sedano, F. J., } \\
\text { Guerrero-Higueras, A. M., Matellán- } \\
\text { Olivera, V., and García-Peñalvo, F. } \\
\text { J. }\end{array}$ \\
\hline 45 & 2017 & $\mathrm{ACM}$ & $\begin{array}{l}\text { Teaching Computational Thinking Using Agile } \\
\text { Software Engineering Methods: A Framework for } \\
\text { Middle Schools }\end{array}$ & $\begin{array}{l}\text { Fronza, I., Ioini, N. E., and Corral, } \\
\text { L. }\end{array}$ \\
\hline 46 & 2017 & CEIE & $\begin{array}{l}\text { Tem Ideia na Rede: Inserindo o Pensamento } \\
\text { Computacional na Rede Municipal de Ensino }\end{array}$ & $\begin{array}{l}\text { Santana, A. L. M., de Jesus, E. A., } \\
\text { Raabe, A., Santana, L., Cucco, L., } \\
\text { and Ramos, G. }\end{array}$ \\
\hline
\end{tabular}

Table 3. Research papers mapped in the final sample. 